\title{
10
}

\section{Conclusions: Differing Contexts, Converging Experiences, Transnational Solidarity}

\section{Ulrike Zschache and Christian Lahusen}

\section{Introduction}

Citizen groups across Europe are engaged in solidarity activism in a wider range of issue fields. Many of these groups and organisations have been active for many years, but this engagement has been stepped up considerably in reaction to the growing social needs and political demands provoked by the various crises that have affected European countries since 2008. The previous chapters have painted a rich picture of the organisational fields in a number of European countries, paying particular

The chapter takes up results of the research project "European paths to transnational solidarity at times of crisis: Conditions, forms, role models and policy responses" (TransSOL), which has received funding from the European Union's Horizon 2020 research and innovation programme under grant agreement No. 649435.

U. Zschache $\bullet$ C. Lahusen $(\bowtie)$

Department of Social Sciences, University of Siegen, Siegen,

Nordrhein-Westfalen, Germany

e-mail: zschache@sozialwissenschaften.uni-siegen.de; lahusen@soziologie.

uni-siegen.de

C. Lahusen et al. (eds.), Transnational Solidarity in Times of Crises, Palgrave Studies in

European Political Sociology, https://doi.org/10.1007/978-3-030-49659-3_10 
attention to smaller and mostly local initiatives engaged in practices of transnational solidarity. In-depth interviews with representatives and activists from these citizen groups and civic organisations were conducted in Denmark, France, Greece, Germany, Italy, Poland, Switzerland and the UK in order to map solidarity work in the fields of unemployment, migration and asylum and disabilities, to better understand the experiences of these organisations, the challenges and constraints they have faced, the action repertoires and strategies they have employed and the national and transnational webs of cooperation they have been involved in. This book offers chapters summarising the main findings of their fieldwork at the grassroots level, giving a vivid account of the situation within each of the countries under analysis. The experiences of the analysed groups and organisations mirror the specificities of the issue field they are working in, as well as the specific features of the socio-economic, political and cultural context of their respective countries. However, the perceptions of the interviewed activists, the experiences they report and the lessons learned share a great number of similarities, testifying that citizen groups, while committed to local activism and restricted to a limited area of operation, seem to be part of a cross-national arena of transnational solidarity work, committed to a similar mission in a context of similar challenges and degradations.

\section{Diverging Contexts and Converging Experiences}

Engaged citizens are aware that solidarity work is confronted with increasing problems and challenges. In most interviews, we heard about growing deprivations, and in part, respondents spoke of apparent moments of crisis. In times of economic recession, mass unemployment, growing precariousness and high immigration, civic groups and organisations have to respond to growing needs, increasing external pressures and limited organisational capacities. Problems have increased in the wake of the financial and economic crisis since 2008, and additional challenges have emerged with the so-called refugee crisis, which announced itself through increasing inflows of refugees in the South European countries, 
culminating in the dramatic summer of 2015. Solidarity groups have been exposed to these crises to varying degrees, depending on the issue field they are operating in and also on the country where they are located. However, accounts and experiences are surprisingly similar, as the various chapters in the book testify.

\section{The Great Recession as a Joint Experience?}

Citizen groups and civic organisations have had to respond to the socioeconomic and financial crisis in a very different way. Greek organisations providing services and help to the unemployed, for instance, had to struggle with far greater difficulties than German unemployment groups or unions. However, it is important to stress that the Great Recession has had an impact on the work of almost all solidarity organisations, across countries and issue fields (Sanchez Salgado 2017; Papadaki and Kalogeraki 2017; Zamponi and Bosi 2018). In particular, three aggravations are mentioned everywhere: the socio-economic degradation due to the financial and economic crisis since 2008, the ongoing retrenchment of the welfare state and a new wave of austerity measures, and a growing disruption of social cohesion (Bermeo and Bartels 2014; Blyth 2013; Schmidt 2016). In most countries, these three elements of crisis are described with similar verve. In Italy and Greece, activists report exposure to economic, political and social degradation. In Poland, France and the UK, respondents stress the gravity of those deprivations that are tied to the political and institutional transformation of the welfare state, whose pace has increased since the outbreak of the financial and economic crisis. Engaged citizens in Denmark and Germany, finally, do not highlight current developments and short-term shocks but argue that the immediate impact of the economic and political aggravations is only part of a more general and long-term development that implies structural deteriorations of social cohesion within society. In this sense it is astonishing that the similarities between perceptions of aggravations and problems prevail, in spite of apparent contextual differences: while countries have been exposed to the Great Recession to varying degrees, activists across all countries share a similar diagnosis of their times, even though they emphasise the various elements of crisis differently. 
In Greece, the conflation of all three elements of crisis was the most notable. Due to the severity and the length of the economic recession, Greek activists report that a considerable share of the Greek population was affected by the harsh fallout from the economic and financial crisis, the implementation of Troika Memoranda and drastic austerity policies. Over a million people lost their jobs, social and health care was minimised due to cuts in public spending, and most Greeks became frustrated and desperate. Also in Italy, interviewees underline that the global economic crisis increased social vulnerabilities, having a devastating impact on deprived population groups, as it increased unemployment and deteriorated the conditions of those living in conditions of precarious work and/or joblessness. In the years between 2010 and 2013, the economic and financial crisis provoked severe cuts in welfare services, which affected not only those groups within society dependent on social benefits but also the prospects of those wishing to be included more proactively in society, such as people with disabilities.

In other countries, the feeling of significant aggravations is shared, even though the financial and socio-economic crisis was not identified as the main catalyst of social degradations. In Poland, TSO representatives could not pinpoint moments of financial strain and economic degradation, given that Poland's economy was little affected by the global and European crisis. However, the Polish government seems to have used the more adverse economic context to push for austerity policies that aimed at the liberalisation and flexibilisation of the labour market, cuts in unemployment rights and welfare benefits for the disabled. In other countries, the Great Recession seems to have expedited a deeper transformation of the welfare state, already well under way at that point in time. Here as well, TSO activists largely agree on welfare retrenchment and austerity policies being the main reason for growing social problems and grievances. In the UK, decades of privatisation seem to go hand in hand with a roll back of the state and immediate impacts of austerity policies, which all had a significant impact on the living conditions of disabled people, sparked numerous redundancies, poorer working conditions and lower levels of labour security, an increase in non-standard forms of employment, and social benefits characterised by sanctions and compulsion. In addition, the sensibility to social degradations was fostered by 
public concerns about potential job losses as a consequence of Brexit. According to French transnational solidarity organisations (TSOs), the global economic crisis nurtured a long-standing process of welfare retrenchment in their country as well. Social degradation is attributed not to the impact of the crisis per se but to austerity measures. The Great Recession is thus perceived as part of a long-term project to reinforce a neoliberal agenda of welfare cuts, privatisation of public services and increased exposure of citizens to market competition. Overall, there is a sense of a gradual welfare retrenchment that is associated with a crisis of the welfare state value and thus, consequently, of social cohesion. Similarly in Denmark, Germany and Switzerland, the perception of living in times of substantial degradation is less tied to specific dates. In particular, the outbreak of the financial and economic crisis is less of a noteworthy event for our respondents in Denmark, Germany and Switzerland. This does not exclude, as some civic organisations indicate, considerable blows to the national labour market, a rising demand for social benefits and growing pressure on public finances, as well as increasing public debt. However, from the perception of activists, these financial and economic shocks were transitory and thus a specific episode of a long-term development. Danish activists, for instance, report that their country was hit much less forcefully by the 2008 financial crisis, and the stagnation in the initial crisis years was soon replaced by an economic recovery. Prior to the financial crisis, however, Denmark had been through a structural reform of the local government system that significantly changed social policies and implied cuts in the distribution of welfare.

German activists agree with this general diagnosis, because the financial and economic crisis of the years 2008 and 2009, which affected the German labour market considerably over a short period, is perceived as part of a long-term process of welfare retrenchment, rising social inequalities and problems, and declining levels of social cohesion and solidarity. Due to the economic recovery and growth in Germany since 2010, problems related to unemployment, social exclusion and poverty disappeared from the public eye, while debates about austerity measures and the financial sustainability of the German social model featured high on the public agenda. Activists are mainly concerned that unemployment and poverty are being pushed off political and media agendas, thus 
contributing to the erosion of solidarity towards concerned societal groups. This also limits the possibilities of promoting the full equity and inclusion of people with disabilities in society.

For respondents from Switzerland, the global and European financial and economic crisis does not seem to have had any marked impact. Yet activists shift attention to the influence of the long-term restructuration of the welfare system. In particular, the development of a system of active labour market policies for unemployed people, or people with difficulties gaining access to the labour market, is seen as a factor that contributes to an increased divide between the insiders and the outsiders of the labour market, as well as a growing opposition between organisations representing the interests of people in employment, on the one hand, and unemployed people, on the other. Similar to their German counterparts, unemployment TSOs are concerned about a lack of public and political awareness of the structural reasons for unemployment, underemployment and poverty, and the erosion of solidarity towards the most vulnerable groups in society.

The current times are thus described as a situation of economic, political and social regression that substantially challenge the work of solidarity groups and organisations, even though activists are steering clear of a wholly doom and gloom portrayal of societal degradation, while underlining moments of change and opportunity. In this sense, the perception of crisis is nurtured by an inherent narrative of risks and opportunities. In regard to risks, our interviews underline that civic groups and organisations have to operate in a more difficult environment, implying more challenges, pressures and limitations. Local TSOs have to meet more needs and demands of unemployed people, migrants and refugees, and disabled citizens. At the same time, they have to operate with fewer (financial) resources, given rising public debt and austerity measures and more competition among civic groups and organisations for a smaller share of public and private funding. In part, these groups see the need to adapt their activities and services in order to survive. Moreover, the relations with public authorities develop more confrontational elements, particularly when groups stress their advocatory mission and militate for defending the political rights of the deprived groups they advocate for. In regard to opportunities, the current situation of crisis and 
regression is also perceived as a situation of growing mobilisation of engaged citizens, the formation of new initiatives and experimentation with more advocatory and participatory action repertoires. Additionally, the activists' accounts testify a growing public awareness about the political underpinnings of socio-economic degradations, stressing the criticism of public policies of austerity, the retrenchment of welfare services and the questioning of citizens' social rights. In this context, solidarity has become more political in that it requires a struggle to preserve and extend social rights, to speak out on behalf of the demands of deprived groups on the fringes of society and to empower and involve them in collective actions.

In Greece, the regressive and permissive repercussions of the crises on the organisational field of TSOs have been most notable. In reaction to the economic recession, the Troika Memoranda, the austerity policies and the growing incapacity of the welfare state to respond, a wide range of solidarity groups and organisations emerged in order to provide direct support to cover basic, everyday needs. Greek respondents report that their country has experienced unprecedented growth in civil society organisations, which have also become stronger and more autonomous from state and partisan control, thus stepping out of the clientelistic framework of previous decades. In other countries, this experience of growth is less marked, given that civil society organisations are more widely spread and integrated into issue field-specific practices of political advocacy and public service provision. Activists thus describe the impact of the adverse economic, political and social circumstances as paradoxical pressures that increase public expectations, while limiting public resources. Italian activists report that they have sought to mitigate the impact of economic breakdown and austerity policies by stepping up both advocacy and service provision. With a certain unease, they see themselves engaged in playing a complementary role to the welfare state, thus correcting the mistakes of current policy developments. Also, British respondents stress that public debt, privatisation and austerity policies are creating a difficult funding environment which limits the ability of organisations to do more work with fewer resources. In addition, Polish respondents add that the lack of public funding cannot be compensated for by donations from members or supporters, thus pulling the plug on certain 
activities and services. They all agree that these aggravations are primarily caused by inadequate government actions. Danish respondents share the conviction that the current situation is marked by a homemade crisis, thus stressing that they have become more critical of their government, which is undermining the traditionally close ties between Danish civil society and municipalities in providing welfare services, not only in the disability sector but also in regard to services for the unemployed, migrants and refugees. Against this backdrop, a more advocatory stance is being adopted by many civic groups, as is true for the situation among French civic groups. This situation, however, is not without contradictions and ambivalences. On the one hand, the retrenchment of the welfare state is increasing the complementary function of civil society organisations in the provision of services, thus opening a door for organisations to professionalise and institutionalise. On the other hand, however, the organisational mission of these solidarity groups is being politicised, underlining the advocatory approach of their work and introducing more confrontational relations with public authorities.

\section{The So-Called Refugee Crisis: Aggravating Contexts and Regressive Tendencies}

Solidarity groups had been confronted with a societal environment that was marked-according to the representatives of these organisations-by regressive tendencies and multiple hardships. The detrimental consequences of the financial and economic crisis and the limitations imposed by public policies of welfare retrenchment have not been, however, the only source of concern to TSOs, given that the so-called summer of migration since 2015 has multiplied problems and challenges for civic groups engaged in the field of migration and asylum and for citizens concerned with the situation of incoming refugees. Also, the so-called refugee crisis has had a differential impact on civic solidarity, even though all countries seem to have been affected to some degree (della Porta 2018; Zamponi 2017; Kousis et al. 2020). Countries on the transit route of refugees fleeing from war, persecution or famine — such as Greece-and countries of destination—such as Germany_experienced a considerable 
mobilisation of civic solidarity as a consequence of the inability of public authorities to respond to human tragedies and individual needs, true also for solidarity groups in the other countries with no or few incoming refugees. Activists testify that the so-called refugee crisis has changed public perceptions and policies, thus calling for more proactive and advocatory work in solidarity with non-citizens, migrants and refugees. While the so-called refugee crisis had positive effects on the mobilisation of support for solidarity initiatives in the short term, activists rather tend to insist on the risks and pressures the summer of migration has brought about in the long term.

The momentum of public mobilisation was the most pronounced in Greece, Germany and Italy, following the reports of TSO representatives. In Greece, solidarity groups committed to fighting social exclusion have stepped up their activities in order to integrate refugees and immigrants, but these activities were not dissociated from initiatives working on behalf of the disabled and/or unemployed people. As a consequence of the dual crisis, many new TSOs were established in the fields of migration, disability and unemployment, and in many cases, members and activists had already been active in civil society organisations and social movements. Civil society has not only experienced moments of considerable growth; it has been exposed to an internal integration in terms of cross-cutting needs, constituencies and demands. The Italian experience deviated in one important aspect from the Greek one, because in Italy, a web of civic groups and organisations working on behalf of migrants and refugees had already been in place, which expanded and intensified their current activities. This has to do also with new funding opportunities for TSOs as an immediate reaction to the so-called refugee crisis, which helped to support the organisational work, mainly concerning services for immigrants and refugees.

The situation in Germany deviates from the Greek and Italian experiences, because the German economy had largely recovered before the high inflow of refugees and migrants from Syria, other regions of the Middle and Far East and Africa. Activists were generally very successful in claiming that Germany had a moral obligation to welcome people fleeing from war and poverty, which led to innumerable new citizen groups, initiatives and volunteers that started to assist the newly arrived asylum 
seekers. This civic engagement was not confined to religious or left antiracists' groups, but it mobilised ordinary citizens across political orientations and social milieus. The informal initiatives and groups were able to emerge across the whole country, also because these organisations could build on a well-developed network of civil society organisations, activists and members. However, welcoming culture and pro-refugee groups were confronted with public reservations from the very beginning, often struggling with committing public authorities to provide sufficient services and goods. Additionally, their activism was paralleled by growing countermobilisations, which tried to discredit their solidarity work and push public opinion towards a more restrictive approach to immigration and integration.

The constraining effect of public hostility has also been experienced by activists from other countries, even though these countries had been much less exposed to the inflows of refugees than Greece and Germany. Denmark and the UK were among those countries with a limited number of Syrian refugees, while Poland resisted any attempts to participate in burden-sharing, even though the number of migrants from Ukraine was quite substantial. TSOs in these countries aimed primarily to confront restrictive immigration and asylum policies that had been introduced by the national government. In Denmark, the so-called refugee crisis provoked a wave of mobilisation, with many citizens volunteering in grassroots movements engaged in practical help and support activities. This mobilisation, however, had to struggle from the very beginning with a public opinion leaning towards populist and anti-immigrant sentiments, thus limiting their scope of activities considerably. Similar to the experience in France, TSOs working on behalf of migrants and refugees are confronted by restrictive migration policies and less supportive programmes of social integration. Under these circumstances, solidarity groups are forced to focus on more urgent needs (such as food, housing and health). Even though many organisations in Italy, France, Denmark and the UK underline their advocatory mission as struggling for the rights of refugees and asylum seekers, their political activism seems to be much more severely challenged within the public sphere. 


\section{Solidarity Activities and Cooperation Structures}

Solidarity groups have been shaped by the aggravating social conditions of their societies. Both crises - the Great Recession since 2008 and the crisis of the European migration regime emerging since 2012-have left their imprint on the organisational fields in all countries under analysis. Even though the exposure to the dual crisis was very different between TSOs, depending on which target groups they addressed and in which countries they operated, it is true that all of them were directly or indirectly affected by growing socio-economic grievances, more restrictive social and immigration policies, and a less permissive and supportive opinion climate in regard to excluded groups. While the Great Recession and the so-called refugee crisis called for more solidarity between European governments and citizens, national policies and public debates tended to regress towards national conceptions of solidarity.

This context has encouraged TSOs to maintain an activism that remains committed to transnational solidarity. The two crises have quite markedly impacted on the organisational fields of TSOs, even in those countries with a short-lived economic downturn and comparatively low numbers of incoming refugees and asylum seekers. They have encouraged activists to broaden the concept of solidarity, given that TSOs questioned more overtly the distinctiveness of different target groups, calling for more integrated, intersectional approaches to meet the needs of the unemployed, migrants or refugees and disabled people, and engaging in a more concerted struggle in favour of an inclusive, open and fair society. While many TSOs have been prioritising the charitable dimension of solidarity when providing services and goods to meet the immediate needs of those groups exposed more severely to the dual crisis, activists across issue fields and countries tend to stress the limitations of such an approach, agreeing on the need for a more political approach to rightsbased advocacy. Additionally, TSOs have seen the need to engage in cooperation and networking activities and to continuously develop their action repertoires in order to more effectively conform to their goals and missions. As we will see in the following, activists in all countries under analysis seem to be part of a shared learning environment. 


\section{Politicisation and Contentiousness}

Unquestionably, this book has something to add to the literature on the subject of the politicisation and contentiousness of TSOs in the three analysed fields of vulnerability. In this regard, some similarities emerge across countries. At the same time, relevant differences exist that require us to draw a more nuanced picture. Generally, it appears that the smaller, grassroots-based and mostly locally embedded solidarity organisations are more often than not political, critical and contentious (also Zamponi and Bosi 2018). Moreover, the findings of most country chapters reveal that action repertoires are in many cases characterised by a strong combination of service provision and political activities (also Zamponi 2019). Hence, many TSOs have a "hybrid" character (Minkoff 2002) and bridge the divide between service- and policy-orientation, evidenced in previous research (Baglioni and Giugni 2014; Baglioni 2001). In direct confrontation with urgent needs and grievances, providing direct help and support is the first response of many solidarity organisations. Nevertheless, many of them pursue a political mission or agenda. What is more, in many instances, TSOs have been duly created out of the political motivation to counterpose and mitigate insufficient public policies in times of state retrenchment, austerity and crises.

On closer inspection, it appears that action repertoires vary notably with respect to different fields and countries. Basically, a first distinction can be made with regard to the question of whether TSOs centre their activities more strongly on service provision or on political action. Secondly, we can distinguish between different types of political activity. On the one hand, there are more moderate and cooperative forms, such as awareness raising, advocacy, lobbying and campaigning. On the other hand, we find more critical, contentious, confrontational and radical forms, involving protest and strike action, and social movement campaigns. There is wide agreement among the findings across the eight countries under review that TSOs from the disability field usually focus more strongly on service provision and that their political activism is mostly based on moderate and cooperative forms of action, like awareness raising, interest representation and lobbying. However, when it 
comes to the other two fields, the findings are not so clear. In large parts, we see that TSOs from the unemployment and migration fields tend to follow a hybrid approach, combining practical help and political mobilisation invariably without prioritising one over the other. To a certain degree, service-oriented and political action are, in fact, inextricably interlinked because providing direct practical help to their target groups is regarded as a political statement in itself. However, this pattern does not apply equally to all countries. In the UK, for instance, there is a clearer division of labour between service- and policy-oriented migration TSOs. Moreover, the smaller, grassroots-oriented unemployment and migration TSOs often appear more critical and contentious compared to the disability TSOs, and a minority of them are indeed quite radical and confrontational. Yet again, this observation is not true for all countries. In Italy, for instance, the analysed TSOs across all three fields are rarely heavily politicised and tend to engage in more moderate forms of political action, like awareness raising, advocacy and lobbying, while only a few are overtly contentious and more radical. This is in sharp contrast to Greece, the second country analysed in this book that is strongly impacted as a consequence of the dual crisis. Here, we found the highest degree of politicisation and radicalism among the smaller, grassroots-oriented TSOs forming the focus of this book.

\section{Cooperation and Transnationalism}

For the smaller scale, grassroots-oriented and mostly locally based citizen groups and organisations, mutual help, sharing and pooling of resources and cooperation with other civil society organisations is an important strategy in order to face hard times of austerity, state retrenchment and crises. Accordingly, trends show that grassroots transnational solidarity organisations have both tightened and expanded their cooperation with others over the past decade. For the vast majority of these groups and organisations, cooperation within the domestic context has been prioritised. Since most of their activities are geared towards responding to urgent needs and grievances in their direct local environment, interrelations of mutual support and exchange with other local initiatives, 
organisations and networks prevail. This local focus applies particularly strongly to the migration and refugee help organisations. In addition, many of the analysed organisations are involved in regional to national forms of cooperation and networking.

Yet, the way in which cooperation is organised differs notably among the fields, and these differences are similarly patterned across countries. Overall, disability organisations typically belong to rather formal national associations or umbrella organisations. Moreover, cooperation and interorganisational relations of solidarity among disability organisations are markedly structured according to particular types of disability or disease, thus leading to considerable fragmentation in this field. In comparison, organisations from the migration and unemployment sector are much more embedded in informal networks and platforms, unless they are trade unions that also tend to be part of formal associations and umbrella organisations. What is more, there seems to be a widespread trend that particularly labour and unemployment organisations, but also organisations from the migration field, respond to the challenges of the past years by building alliances with and extending their solidarity relations towards organisations and networks from a broad range of other sectors and issue fields, including precarity and atypical working conditions, poverty, migration, housing, rising nationalism, anti-neoliberalism, austerity or women's and ethnic minorities' rights. They bridge differences, identify common concerns and join forces in order to mobilise broader constituencies, enhance public and political attention and promote political change (also Diani 2018; Gumbrell-McCormick 2011; Kirton and Greene 2005; Marino et al. 2015). The latter also reflects the fact that most organisations from the unemployment and migration fields pursue a political mission and engage in political action. Indeed, observed differences in the type of cooperation and networking should not be attributed to the field of activity alone. We also have to remember that the three analysed fields differ in their degree of contentiousness. As described previously, disability TSOs tend to be more service-oriented and more moderate and consensus-oriented in their political activities (such as awareness raising, lobbying and campaigning), while unemployment and migration TSOs are often more politicised, critical, contentious and protestoriented. These variations in the level of contentiousness further translate 
into the ways in which inter-organisational relations are coordinated and organised.

If cooperation within national contexts prevails, what is the proper role of transnational exchange and collaboration? In this regard, the findings of this book provide striking evidence that smaller scale, grassrootsoriented solidarity organisations are engaged in activities of transnational solidarity, but it follows unique patterns that distinguish it from the more salient transnationalism of larger and more formalised civil society organisations (Kohler-Koch and Buth 2013; Sanchez Salgado 2014). Indeed, as we have already proposed elsewhere (Kousis et al. 2020; Lahusen 2020), the country studies at hand corroborate and illustrate in detail that smaller, mostly informal and locally based citizen groups and organisations are more likely to pursue forms of soft transnational solidarity that involve rather loosely coupled, horizontal forms of cooperation and informal networking across different countries. Moreover, the locally embedded and grassroots-centred action repertoires through which TSOs respond to urgent needs and demands in their direct environment translate further into forms of transnational cooperation that have a decentralised structure and are immediately bound to specific local organisations and/or constituencies in other countries. In other words, transnational solidarity manifests itself primarily as cross-national cooperation between different local groups (also Lahusen et al. 2018; Mattoni and della Porta 2014; Tarrow 1998). It consists typically of information exchange and sharing ideas, learning about best practices and potential solutions to current challenges across borders. Furthermore, such loose forms of transnational cooperation comprise ad-hoc campaigning and collaboration of different local groups or grassroots organisations in specific, nonformalised ad-hoc projects. In a small number of cases, cross-national cooperation also involves direct service provision and financial support for local (self-help) groups and people in need living in less developed regions of the world. In comparison, forms of hard or strong transnational solidarity, where cross-national activities are coordinated in a more formal and structured way, play only a secondary role. Cooperation is seldom organised in formalised European or transnational platforms, networks or campaigns. Some TSOs engage in joint transnational projects that are funded, for instance, by the EU or other international 
funding sources, which can also be regarded as a form of stronger, more systematic transnational cooperation.

In addition, the minority of the analysed solidarity organisations are involved in forms of vertical Europeanisation, thus participating in a "scale shift" (Tarrow and McAdam 2005) towards the EU (also KohlerKoch 2010; Kohler-Koch and Quittkat 2013; Monforte 2009; Sanchez Salgado 2017; Taylor and Mathers 2004). Here, TSOs are organised as members of a more formalised European or international umbrella organisation, platform or network-either directly or indirectly through their national umbrella organisation. Through their membership, these TSOs can benefit from the advocacy, lobbying and campaigning activities of their umbrella organisations and thus gain access to legislative processes and consultations at the supra- or transnational level.

Moving beyond the distinction between (soft or strong) horizontal and vertical solidarity interlinkages, the country chapters of this book evidence that both the prevalent type and the extent of transnational solidarity are pre-structured by a set of different factors. Firstly, and similar to domestic forms of cooperation, the very field of activity and the degree of contentiousness make a difference as to whether TSOs privilege soft or hard transnational solidarity practices. Soft forms of transnational solidarity are predominant in the migration field and widely diffused among TSOs from the unemployment field. TSOs pursuing soft transnationalism are also those that are often more politicised and critical and, in many cases, also more contentious and protest-oriented. These types of transnational solidarity organisations opt for horizontal relations of reciprocity and mutual exchange because they target the grassroots level of direct demands and grievances. However, due to their critical and often contentious character, they also aim to avoid the adaptive pressures implied by more formalised and vertical forms of Europeanisation (Kohler-Koch and Buth 2013; Sanchez Salgado 2014). In comparison, stronger forms of horizontal cooperation and vertical Europeanisation are more common among TSOs from the disability field, trade unions and some employment-oriented TSOs. These interlinkages manifest themselves mainly in the membership of a transnational network or European umbrella organisation, or sometimes of structured projects or programmes on the basis of EU funds, such as Erasmus+ and the European 
Social Fund. TSOs favouring harder, more formalised or fixed forms of transnational solidarity and/or vertical Europeanisation tend to be more service-oriented and apply a more consensus-oriented, mainstream approach to their political activities.

Secondly, the extent and type of transnational solidarity relations are decisively influenced by organisational capacities and the exploitation of external opportunities. The extent, intensity and eventually also the question of loose and ad-hoc or more structured transnational cooperation are to a significant degree conditional upon organisational resources. Many respondents across the different countries reported that they could barely afford to engage systematically in transnational cooperation and networking. What is more, existing transnational interlinkages often had to be scaled back or given up in recent years due to the immense workload they encounter in their direct environments at home. Relocating their efforts from the European to the local (and national) level of cooperation has clearly been prioritised in times of state retrenchment, austerity and crises. This observation applies most strongly to the small, informal citizen groups and organisations operating exclusively with volunteers. In comparison, organisations that are somewhat larger tend to be more resourceful and are better prepared to engage more systematically and strongly in transnational solidarity relations. In part, these organisations are also more formalised and involve some paid staff. Thus, the question of whether and how a solidarity organisation can afford to become active transnationally is largely a matter of size and partly due to the degree of formalisation (Durán Mogollón et al. 2020).

At the same time, size and formalisation have an influence on an organisation's readiness to seize external opportunities, such as access to an additional arena of lobbying and influence-taking on political decisions and to new, alternative funding sources at the supra- and transnational level (also Kousis 1999; Císař and Vráblíková 2013; Sanchez Salgado 2017). In this regard, once again the bigger and more formalised solidarity organisations are able to utilise these opportunities. As discussed earlier, a higher degree of formalisation often goes hand in hand with an organisation's membership of formal European umbrella organisations or networks. Hence, through this membership, the more formal TSOs may seek to impact on supranational policy-making in order to 
compensate for insufficient influence-taking at home. In addition, country reports similarly point out that it is mostly the larger and often the more formal TSOs that have the capacities to apply for funding from European and transnational funding sources in order to make up for reductions in and harsh competition over domestic funding and as a way to respond to rising demands among their constituencies. In particular, the financial opportunities offered by supra- and transnational funding are a driving force for them to engage in structured joint European and transnational projects and more long-lasting collaborations with partners from abroad. In contrast, smaller, informal, low-resourced TSOs usually do not have the capacity to apply for EU and transnational forms of funding (with uncertain success), as they have to focus their resources on the pressing demands in their immediate environments (also Lahusen 2014). Thus, what we see is that the already better-equipped TSOs are the ones that are able to take advantage of supra- and transnational opportunities to further secure their survival in hard times of state retrenchment and crises, while those that are already struggling to make ends meet are in a disadvantaged position. At the same time, though, we need to remember that higher degrees of contentiousness may also lead them to distance themselves more overtly from the EU as a system of governance.

\section{Social Learning and Innovation}

A third major finding is that the solidarity work of the analysed groups and organisations is considerably shaped by collective learning processes. Respondents from the different countries widely agree that they have developed and employed new approaches and practices in recent years in order to respond to changing social realities and new challenges in times of austerity, state retrenchment and crises. Indeed, they report that poor resources and insufficient or transformed political frameworks, on the one hand, and a surge of people in need of support as well as a rise of new grievances and demands, on the other, have urged them to adapt their strategies, concepts and activities to these new circumstances. In addition, new practices have emerged because of TSOs making use of new 
opportunities and adapting to new routines of constituencies and stakeholders, particularly with regard to the latest communication technologies. Overall, these revised and altered approaches and practices are not, per se, completely new. Nevertheless, they involve innovative elements because of the ways in which these solidarity groups and organisations experiment with new activities and instruments or adjust existing ones in order to respond to new needs and cope with transformed circumstances (also Kousis and Paschou 2017; Papadaki and Kalogeraki 2017; Zamponi and Bosi 2018).

Across the different country chapters, a number of similar patterns have emerged. First of all, interviewees from various countries reported that their group or organisation extended the scope of solidarity towards new target groups that usually did not belong to their core constituency. In practical terms, this meant an expansion and adaptation of the TSOs' repertoire of action in order to be more inclusive, reach out to more diverse beneficiaries and target multiple and partly intersectional needs. On the one hand, this broadening of solidarity action is a means to cope with upcoming urgent needs and to adapt to changing grievances and demands (for instance, due to an increase of migrants and refugees, the flexibilisation and precarisation of employment conditions); on the other, it is a strategy to safeguard an organisation's survival in the face of multiple crises, restructuring of the welfare state and austerity. While this trend emerged in most of the countries under review, there are notable differences as regards the fields of vulnerability. Indeed, broadening the scope of solidarity action and opening up to new target groups is most prominent among unemployment organisations and trade unions (also Diani 2018; Gumbrell-McCormick 2011; Kirton and Greene 2005; Marino et al. 2015), while it is almost absent among organisations from the highly fragmented disability field. In addition, there are also exceptions to the general observation of an expansion of solidarity. Interviews with TSOs from Switzerland, for example, showed that both migration and (un)employment organisations work for closely defined and almost mutually exclusive circles of beneficiaries, reflecting distinct policy traditions and frameworks and a related functionalist approach towards target groups. Indeed, according to the interviews, fragmentation and specialisation are so far-reaching that there are hardly any interlinkages, save for 
opposition, between Swiss unemployment organisations, on the one hand, and trade unions and other labour-related organisations, on the other.

Secondly, and resonating well with the broadening of target groups, several TSOs across different countries led enhanced efforts to engage in new forms of alliance building with a broad range of organisations, networks and movements from other areas and fields. Bridging differences, identifying common concerns and aims, and joining forces on behalf of them is a strategy that has gained momentum in recent years in order to reinforce public and political attention, renew organisational legitimacy foundations and increase the policy impact (also Borland 2010; Diani 2018). Again, this approach was reported in particular by organisations from the unemployment field (including trade unions) (also Milner and Mathers 2013), while it was only marginally addressed by TSOs from the other two fields.

Thirdly, establishing new solidarity groups and organisations is another salient form of response to crises, changed circumstances and resultant new grievances and needs. Many respondents underlined that their group or organisation was created during and due to the recent economic and/ or migration policy crisis because the state and existing civil society organisations appeared to be insufficiently prepared to cope with the pressing direct needs at the grassroots level. While new unemployment TSOs were mainly founded in countries with a shorter history of civic participation, like Greece, new migration and refugee help groups and organisations emerged in a larger number of countries that were directly or indirectly affected by the recent rise in the arrival of migrants and refugees in Europe (also Baumgarten 2017; della Porta 2018; Kousis and Paschou 2017; Sotiropoulos and Bourikos 2014; Vathakou 2016; Zamponi 2017). Given that this organisational field is comparably young, diversification and emancipation from the established large charity organisations is just a recent development, providing momentum for the emergence of new and alternative collective actors in the field. Yet, the economic and refugee crises were not the only circumstances that encouraged the establishment of new TSOs. To some extent, it was also the redesign of welfare systems, state retrenchment and austerity that triggered the creation of solidarity organisations seeking to respond to 
newly arising concerns and grievances and to meet the needs of new vulnerable groups (also White 2015).

Moreover, the findings across various country chapters show that the smaller, grassroots-oriented and often rather informal TSOs have developed a specific bottom-up understanding of solidarity. This bottom-up approach privileges horizontal relations between providers and receivers of solidarity action, building on ideas of reciprocity, mutualism, equality and participation. It is opposed to a vertical, top-down solidarity approach guided by philanthropic and humanitarian ideas. TSOs favouring a bottom-up conception of solidarity aim to overcome relations of charity and care because they do not want to treat their beneficiaries as passive objects of help (Fernández G. G. et al. 2020). Instead, empowerment, emancipation, self-initiative and self-representation, as well as the realisation of human rights, are their important guiding principles. The bottom-up solidarity approach is not in itself new and was already practised among smaller, locally based solidarity organisations in previous decades (Moulaert and Ailenei 2005). However, the enhanced restructuration of welfare states, harsh austerity policies and the impact of the economic and migration policy crisis as well as the growing importance of the human rights discourse (e.g., with regard to the rights of disabled persons or refugees) provided an important impetus for the proliferation of this concept. In this respect, the findings suggest in particular that these circumstances provided momentum for the diffusion of a bottom-up approach as they opened a window of opportunity for the engagement of new individual and collective actors from different backgrounds, and with alternative and often critical and politicised visions and understandings.

At the same time, this bottom-up approach of solidarity appears to shape the notion of inter-organisational relations and transnational solidarity. As mentioned earlier, the smaller, grassroots-oriented and mostly locally embedded TSOs analysed tend to engage in horizontal, decentralised and more informal, loose forms of soft transnational cooperation and networking with local-level partners, rather than vertical and more formal forms of hard transnationalism. Similar to relations with beneficiaries, the principles of reciprocity and mutualism are valued highly. And even when transnational cooperation involves a certain asymmetry (mostly in cases with partners from outside the EU), TSOs are 
committed to empowering local partners through capacity building, responsibility sharing and leaving the implementation of solidarity activities to the local organisations. The importance of this bottom-up approach of transnational solidarity is closely interlinked with the fact that the smaller grassroots-based TSOs analysed in this book, apart from being concerned with direct needs and grievances in their local environments, are more critical, contentious and politicised in their missions and practices. Against this backdrop, they seem to favour and work towards the establishment of an alternative concept of transnational solidarity that builds an active and critical transnational civil society across borders from below (Kousis et al. 2020).

Finally, collective learning processes widely involve the development and use of new forms of communication and outreach. In this respect, the transnational solidarity organisations analysed in this book contribute to a general development among social movement and civil society groups and organisations towards digitalisation and internet activism (Bennett and Segerberg 2013; Earl and Kimport 2013; Earl and Rohlinger 2018; Kousis et al. 2018). Websites, internet platforms and social media have become important channels to engage more efficiently and interactively with target groups and stakeholders. A number of TSOs also led considerable efforts to experiment with and create new online tools, platforms and mobile apps as a proper service instrument for their constituencies.

While many of our interviewees reported having used the recent challenges in the face of austerity, state retrenchment and crises as an opportunity for learning and the development and usage of new approaches and practices, there were also some voices that uttered scepticism in this regard. Concerns were most explicitly expressed by representatives of various service-oriented, small TSOs from France, which suffered the harshest competition over funding in an efficiency-driven system where performance is measured in pure numbers. Against this backdrop, these TSOs had little margin to experiment with alternative approaches and practices if they wanted to survive. As a result, several TSOs that used to be creative in the past, lost their innovative and original character in order to stay afloat in times of state retrenchment and austerity. 


\section{Outlook}

Civic groups and organisations have testified their ability to support vulnerable groups in times of crisis. Most of these groups are committed to a local scope of operation, thus mirroring a grassroots approach to solidarity that allows them to mobilise active citizens in support of emerging needs in their immediate surroundings. This web of civic initiatives and groups is part and parcel of a transnational arena of civic engagement because these groups feature aims, activities, beneficiaries, contacts and collaborations that transcend local and national physical and imagined borders. The analysis of civic engagement in the fields of unemployment, disabilities and migration has shown that this wide range of TSOs is confronting a growing challenge. Activists across our eight countries tend to converge in the opinion that their capacity to work is being limited by a social and political context exposed to regressive tendencies (for instance, reduced public funding, restrictive social rights or counter-mobilisations), while the range of needs they wish to meet and the issues they are committed to speaking out on is increasing. Overall, civic groups and organisations are currently Europe's fire brigade, responding to societal problems that await political solutions. This organised civic solidarity, however, is exhibiting moments of fatigue and retreat, resulting from the intensity of activities in the dual crisis period.

The experiences of civic solidarity groups thus highlight urgent challenges that need to be addressed. Public and private funding is often short term and discontinued; moreover, funding schemes at local, national and EU levels are poorly coordinated. Activists are also concerned about the side effects of established policies, given that social policies limit the engagement of welfare recipients as non-formal work experience is not recognised or even prohibited. Additionally, legal and financial exigencies encourage the professionalisation, formalisation and bureaucratisation of their work, which means that formal, professionalised and larger organisations seem to benefit in the eyes of many activists, to the detriment of newer and smaller citizen groups. Additionally, civic solidarity seems to depend on a proactive welfare regime. It is true that several TSOs are engaged in alternative forms of organisation and problem-solving beyond 
the institutionalised welfare state. These activities involve alternative forms of production and consumption (such as food banks, collective purchasing groups, repair cafés, free legal advice or medical services), which are often tied to political forms of contestation and protest. Many of these initiatives and groups see their main aim as promoting empowerment; they do not see their role as auxiliaries of the established welfare system but define themselves as instruments of social change. However, most activists militate for a more proactive welfare state, because they highlight the responsibility of the welfare state to promote and support solidarity, for instance, by granting social rights that guarantee greater equality, inclusion and integration.

Finally, most initiatives, groups and organisations described in our chapters are engaged in solidarity work with a primarily local focus. While most activists stress that their activism is marked by elements of transnational solidarity, when taking into consideration the organisational goals, partners or beneficiaries, the range of organisations engaged in a truly European scope of activities is more restrained and more diffused among TSOs with a higher proportion of formalised groups with Europeanised organisational structures (Kousis et al. 2020). Most activists stress the merit and necessity of transnational cooperation, yet, in practice, structured forms of transnational cooperation often play a rather marginal role. This has to do with many practical challenges, for instance, problems of language barriers, the high workload concerning the TSOs' core activities and the little added-value of transnational cooperation for their immediate activism. However, TSOs are legally and financially tied to the nation-state when looking at funding opportunities, legal status or taxation policies. Even though the European Charter of Fundamental Rights grants freedom of assembly and association at all levels explicitly, there is still no European legal framework encouraging and promoting European associations. Overall, it needs underscoring that civic solidarity is not an incessantly chugging resource, a horn of plenty, but a practice that is exposed to situations of overburdening and is thus in need of concerted public care and concern. 


\section{References}

Baglioni, S. (2001). Solidarity Movement Organizations: Toward an Active Global Consciousness? In M. Giugni \& F. Passy (Eds.), Political Altruism? (pp. 219-234). Lanham, MD: Rowman \& Littlefield.

Baglioni, S., \& Giugni, M. (2014). Civil Society, Unemployment and Precarity in Europe: An Introduction. In S. Baglioni \& M. Giugni (Eds.), Civil Society Organizations, Unemployment, and Precarity in Europe. Between Service and Policy (pp. 1-10). London: Palgrave Macmillan.

Baumgarten, B. (2017). Back to Solidarity-Based Living? The Economic Crisis and the Development of Alternative Projects in Portugal. Partecipazione e Conflitto, 10(1), 169-192.

Bennett, W. L., \& Segerberg, A. (2013). The Logic of Connective Action: Digital Media and the Personalization of Contentious Politics. Cambridge: Cambridge University Press.

Bermeo, N., \& Bartels, L. M. (Eds.). (2014). Mass Politics in Tough Times: Opinions, Votes and Protest in the Great Recession. Oxford: Oxford University Press.

Blyth, M. (2013). Austerity: The History of a Dangerous Idea. Oxford: Oxford University Press.

Borland, E. (2010). Crisis as a Catalyst for Cooperation? Women's Organizing in Buenos Aires. In N. van Dyke \& H. J. McCammon (Eds.), Strategic Alliances: Coalition Building and Social Movements (pp. 241-265). Minnesota: University of Minnesota Press.

Císař, O., \& Vráblíková, K. (2013). Transnational Activism of Social Movement Organizations. The Effect of European Union Funding on Local Groups in the Czech Republic. European Union Politics, 14(1), 140-160.

della Porta, D. (Ed.). (2018). Solidarity Mobilizations in the 'Refugee Crisis'. Contentious Moves. Cham: Palgrave Macmillan.

Diani, M. (2018). Unions as Social Movements or Unions in Social Movements? In J. Grote \& C. Wagemann (Eds.), Social Movements Organized Labour. Passions Interests (pp. 43-65). London: Routledge.

Durán Mogollón, L., Eisele, O., \& Paschou, M. (2020). Applied Solidarity in Times of Crisis: Exploring the Contexts of Civil Society Activities in Greece and Germany. Acta Politica, online first: https://doi.org/10.1057/ s41269-020-00154-8.

Earl, J., \& Kimport, K. (2013). Digitally Enabled Social Change: Activism in the Internet Age. Cambridge: MIT Press. 
Earl, J., \& Rohlinger, D. A. (Eds.). (2018). Social Movements and Media. Bingley: Emerald.

Fernández G. G., E., Kousis, M., \& Lahusen, C. (2020, forthcoming). Does Organization Matter? Solidarity Approaches of Transnational Organizations Across Eight European Countries. Sociological Research Online.

Gumbrell-McCormick, R. (2011). European Trade Unions and 'Atypical' Workers. Industrial Relations Journal, 42(3), 293-310.

Kirton, G., \& Greene, A.-M. (2005). Gender, Equality and Industrial Relations in the 'New Europe': An Introduction. European Journal of Industrial Relations, 11(2), 141-149.

Kohler-Koch, B. (2010). Civil Society and EU Democracy. 'Astroturf' Representation? Journal of European Public Policy, 17(1), 100-116.

Kohler-Koch, B., \& Buth, V. (2013). The Balancing Act of European Civil Society: Between Professionalism and Grass Roots. In B. Kohler-Koch \& C. Quittkat (Eds.), De-mystification of Participatory Democracy. EU Governance and Civil Society (pp. 114-148). Oxford: Oxford University Press.

Kousis, M. (1999). Sustaining Local Environmental Mobilisations. Groups, Actions and Claims in Southern Europe. Environmental politics, 8(1), 172-198.

Kousis, M., \& Paschou, M. (2017). Alternative Forms of Resilience. A Typology of Approaches for the Study of Citizen Collective Responses in Hard Economic Times. Partecipazione e Conflitto, 10(1), 136-168.

Kousis, M., Giugni, M., \& Lahusen, C. (2018). Action Organization Analysis: Extending Protest Event Analysis Using Hubs-Retrieved Websites. American Behavioral Scientist, 62(6), 739-757.

Kousis, M., Loukakis, A., Paschou, M., \& Lahusen, C. (2020). Waves of Transnational Solidarity Organisations in Times of Crises: Actions, Obstacles and Opportunities in Europe. In C. Lahusen (Ed.), Citizens' Solidarity in Europe. Civic Engagement and Public Discourse in Times of Crisis (pp. 55-84). Cheltenham: Edward Elgar.

Lahusen, C. (2014). Mind the Gap: Local Civil Society Organizations and the European Union. In S. Baglioni \& M. Giugni (Eds.), Civil Society Organizations, Unemployment, and Precarity in Europe. Between Service and Policy (pp. 204-228). Houndmills, Basingstoke: Palgrave Macmillan.

Lahusen, C. (2020). Conclusion: The Entangled Paths Towards European Solidarity. In C. Lahusen (Ed.), Citizens'Solidarity in Europe. Civic Engagement and Public Discourse in Times of Crisis (pp. 177-191). Cheltenham: Edward Elgar. 
Lahusen, C., Kousis, M., Zschache, U., \& Loukakis, A. (2018). European Solidarity in Times of Crisis: Comparing Transnational Activism of Civic Organisations in Germany and Greece. Österreichische Zeitschrift für Soziologie, 43(1), 173-197.

Marino, S., Penninx, R., \& Roosblad, J. (2015). Trade Union, Immigration and Immigrants in Europe Revisited: Unions' Attitudes and Actions Under New Conditions. Comparative Migration Studies, 3(1), 1-16.

Mattoni, A., \& della Porta, D. (2014). Adapting Theories on Diffusion and Transnational Contention through Social Movements of the Crisis: Some Concluding Remarks. In D. della Porta \& A. Mattoni (Eds.), Spreading Protests. Social Movements in Times of Crisis (pp. 277-292). Colchester: ECPR Press.

Milner, S., \& Mathers, A. (2013). Membership, Influence and Voice: A Discussion of Trade Union Renewal in the French Context. Industrial Relations Journal, 44(2), 122-138.

Minkoff, D. C. (2002). The Emergence of Hybrid Organizational Forms: Combining Identity-Based Service Provision and Political Action. Non-profit and Voluntary Sector Quarterly, 31(3), 377-401.

Monforte, P. (2009). Social Movements and Europeanization Processes. The Case of the French Associations Mobilizing Around the Asylum Issue. Social Movement Studies, 8(4), 409-425.

Moulaert, F., \& Ailenei, O. (2005). Social Economy, Third Sector and Solidarity Relations: A Conceptual Synthesis from History to Present. Urban Studies, 42(11), 2037-2053.

Papadaki, M., \& Kalogeraki, S. (2017). Social Support Actions as Forms of Building Community Resilience at the Onset of the Crisis in Urban Greece: The Case of Chania. Partecipazione e Conflitto, 10(1), 193-220.

Sanchez Salgado, R. (2014). Europeanizing Civil Society. How the EU Shapes Civil Society Organizations. New York: Palgrave Macmillan.

Sanchez Salgado, R. (2017). Europeanization of Civil Society Organizations in Times of Crisis? Exploring the Evolution Grant-Seeking Strategies in the EU Multi-Level System. European Politics and Society, 18(4), 511-528.

Schmidt, V. A. (2016). Reinterpreting the rules 'by stealth' in times of crisis: a discursive institutionalist analysis of the European Central Bank and the European Commission. West European Politics, 39(5), 1032-1052.

Sotiropoulos, D. A., \& Bourikos, D. (2014). Economic Crisis, Social Solidarity and the Voluntary Sector in Greece. Journal of Power, Politics and Governance, 2(2), 33-53. 
Tarrow, S. (1998). Power in Movement: Social Movements and Contentious Politics. New York: Cambridge University Press.

Tarrow, S., \& McAdam, D. (2005). Scale Shift in Transnational Contention. In D. Della Port \& S. Tarrow (Eds.), Transnational Protest and Global Activism. People, Passions and Power (pp. 121-150). Lanham: Rowman \& Littlefield. Taylor, G., \& Mathers, A. (2004). The European Trade Union Confederation at the Crossroads of Change? Traversing the Variable Geometry of European Trade Unionism. European Journal of Industrial Relations, 10(3), 267-285.

Vathakou, E. (2016). Citizens' Solidarity Initiatives in Greece During the Financial Crisis. In J. Clarke, A. Huliaras, \& D. A. Sotiropoulos (Eds.), Austerity and the Third Sector in Greece: Civil Society at the European Frontline (pp. 167-189). London: Routledge.

White, G. (2015). Social movements and social policies. Contention, 3(2), 17-32. Zamponi, L. (2017). Practices of Solidarity: Direct Social Action, Politicisation and Refugee Solidarity Activism in Italy. Mondo Migranti, 3, 97-117.

Zamponi, L. (2019). Direct social action, welfare retrenchment and political identities. Coping with the crisis and pursuing change in Italy. Partecipazione e Conflitto, 12(2), 382-409.

Zamponi, L., \& Bosi, L. (2018). Politicizing Solidarity in Times of Crisis: The Politics of Alternative Action Organizations in Greece, Italy, and Spain. American Behavioral Scientist, 62(6), 796-815.

Open Access This chapter is licensed under the terms of the Creative Commons Attribution 4.0 International License (http://creativecommons.org/licenses/ by/4.0/), which permits use, sharing, adaptation, distribution and reproduction in any medium or format, as long as you give appropriate credit to the original author(s) and the source, provide a link to the Creative Commons licence and indicate if changes were made.

The images or other third party material in this chapter are included in the chapter's Creative Commons licence, unless indicated otherwise in a credit line to the material. If material is not included in the chapter's Creative Commons licence and your intended use is not permitted by statutory regulation or exceeds the permitted use, you will need to obtain permission directly from the copyright holder. 